\title{
Kemandirian Anak Usia Usia 5-6 Tahun dengan Ibunya yang Bekerja Paruh Waktu
}

\author{
Tita Norma Gita ${ }^{1}$, Nurbiana Dhieni' ${ }^{1}$, Sri Wulan ${ }^{1}$ \\ Pendidikan Anak Usia Dini, Universitas Negeri Jakarta, Indonesia(1) \\ DOI: $10.31004 /$ obsesi.v6i4.1032
}

\begin{abstract}
Abstrak
Penelitian ini dilakukan bertujuan untuk mendeskripsikan serta mengetahui lebih dalam tentang Peran Ibu Bekerja Paruh Waktu Dalam Menumbuhkan Kemandirian anak usia 5-6 tahun. Subjek penelitian adalah 2 ibu dan 2 anak. Metode penelitian yang digunakan adalah penelitian kualitatif dengan studi kasus. Pengumpulan data dilakukan dengan cara dokumentasi, wawancara, observasi, catatatan lapangan.teknik analisis data yang digunakan adalah miles and huberman. Hasil temuan penelitian ini yakni peran ibu dalam keluarga yakni bekerja di pasar, memenuhi gizi anak, memberikan pendidikan, memberikan contoh perilaku yang baik bagi anak. Dimensi kemandirian anak antara lain: perilaku, emosional, nilai. Strategi yang mendukung ibu bekerja paruh waktu dalam menumbuhkan kemandirian anak usia 5-6 tahun.
\end{abstract}

Kata kunci: dimensi kemandirian; anak usia dini; peran ibu; strategi ibu; ibu bekerja

\begin{abstract}
Mother has a very important role for the family. The mother acts as an educator for the child and the mother acts as the fulfillment of the basic needs of the child. Apart from being housewives, some mothers also work part-time working hours ranging from less than 4 to 6 hours per day. This research aims to examine to describe and to know more about the role of part-time working mothers in fostering the independence of children aged 5-6 years. The research subjects were 2 mothers and 2 children. The research method used is qualitative research with case studies. Data collection was done by means of documentation, interviews, observations, field notes. Data analysis techniques used were miles and huberman. The findings of this study are the role of mothers in the family, namely working in the market, fulfilling children's nutrition, providing education, providing examples of good behavior for children. The dimensions of children's independence include: behavior, emotion, values. Strategies that support part-time working mothers in fostering independence for children aged 5-6 years.
\end{abstract}

Keywords: dimensions of independence; early childhood; mother's role; mother strategy; mother working

Copyright (c) 2022 Tita Norma Gita, et al.

$\triangle$ Corresponding author:

Email Address: titanormagita@gmail.com (Jakarta, Indonesia)

Received 5 January 2021, Accepted 29 July 2021, Published 31 January 2022 


\section{PENDAHULUAN}

Anak merupakan generasi penerus bangsa yang akan bertanggung jawab atas eksistensi bangsa di masa depan. Kemajuan bangsa Indonesia ditentukan oleh pendidikan yang dicapai oleh anak-anak. Pelibatan keluarga dalam penyelenggaraan pendidikan adalah hal penting dan strategis dalam mendukung penyelenggaraan pendidikan untuk mencapai tujuan pendidikan nasional. Pelibatan keluarga dalam penyelenggaraan pendidikan memerlukan sinergi antara orang tua, pendidik, dan masyarakat. Peraturan Menteri Pendidikan dan Budaya Nomor 30 tahun 2017 memiliki prinsip-prinsip pelibatan keluarga pada penyelenggaraan pendidikan yaitu persamaan hak,saling asah, asih dan asuh serta mempertimbangkan kebutuhan dan aspirasi anak. Banyak cara kegiatan keterlibatan keluarga yang mendukung anak dalam proses pendidikan (Hukum, Organisasi, Pendidikan, \& Kebudayaan, 2017). Keterlibatan keluarga pada proses pendidikan dapat berupa: menumbuhkan nilai-nilai karakter anak di lingkungan keluarga, memotivasi semangat belajar anak, mendorong budaya literasi dan memfasilitasi kebutuhan belajar anak (Hukum, Organisasi, Pendidikan, \& Kebudayaan, 2017).

(Weiss et al, 2013) pada hasil penelitiannya menyebutkan bahwa ibu yang bekerja penuh waktu akan sedikit terlibat untuk mendidik anak-anaknya. Sedangkan ibu bekerja dengan paruh waktu (dengan gaji lebih rendah) mampu meluangkan waktu bersama keluarga dan mengasuh anak-anaknya dengan baik. Sehingga ibu yang bekerja paruh waktu memiliki waktu yang banyak untuk menjalankan peran sebagai seorang wanita yakni melakukan pekerjaan rumah, mengurus keluarga serta mengasuh anak-anaknya.

Observasi pra penelitian yg dilakukan oleh peneliti pada bulan Februari 2020 mewawancarai sebanyak 3 orang ibu-ibu yang bekerja di Pasar Sekaran dengan berjualan baju serta memiliki anak usia dini dari usia 5-6 tahun. Jam buka toko tersebut dimulai pukul 07.30 hingga jam 12.30. Observasi awal dilakukan peneliti untuk mengetahui pendapat para orang tua yang memiliki anak usia dini. Observasi awal mendapatkan hasil tentang pandangan masyarakat terhadap sikap dan perilaku anak-anak yang ditinggal oleh orang tuanya bekerja di Pasar Sekaran. Kemandirian anak juga tertanam pada saat anak melakukan aktivitas di luar rumah. Bentuk kemandirian di luar rumah misalnya terbiasa berangkat dan pulang sekolah atau ngaji tanpa dijemput, bermain di rumah tetangga tanpa di antarkan oleh orang tua. Yang menjadi keunikan dalam penelitian ini pada saat orang tuanya ke surabaya. Waktu yang dibutuhkan dari lamongan ke surabaya dibutuhkan waktu tempuh selama 2 jam (ayah mengantarkan ibu berbelanja pakaian untuk di jual kembali di Pasar) dari jam 11.00 hingga 20.00 . Anak-anak berada di rumah tanpa didampingi oleh orang dewasa sampai orang tuanya kembali ke rumah. Anak merasa nyaman di rumahnya didukung oleh teman-teman sebayanya yang sering mengajak sholat (Adzan atau iqomah secara bergantian di musholla dekat rumahnya tersebut), selain itu berangkat ngaji bersama-sama. selain itu pada saat anak di rumah melakukan segala aktivitas sendiri mulai dari ganti pakaian, menyiapkan makanannya sendiri. Serta sebagian anak sering bermain kerumahnya untuk sekedar makan bersama dan bermain yang menjadi faktor anak bersedia ditinggal oleh orang tuanya

Terkait dengan kondisi yang ditemukan oleh peneliti pada observasi pra penelitian tentang peran ibu bekerja di pasar bagi anak yang dilakukan pada bulan februari 2020 juga pernah dilakukan sebelumnya tentang peran ibu bekerja dalam pemenuhan kebutuhan dasar anak dengan penelitian studi kasus (Fitriyani, Nurwati, \& Humaedi, 2016). Penelitian ini memiliki kesamaan yakni membahas peran ibu bekerja. Perbedaan pada penelitian ini yakni pada penelitian sebelumnya membahas tentang peran ibu bekerja dalam pemenuhan kebutuhan dasar. Adapun kebutuhan dasar meliputi asuh kebutuhan fisik-biologis, asih kebutuhan kasih sayang, asah kebutuhan stimulasi

Dalam hasil penelitian (Nauli, Karnadi, \& Meilani, 2019) tentang Peran Ibu Pedagang Pasar 24 Jam terhadap Perkembangan Moral Anak (penelitian studi kasus di Kota Bekasi). penelitian ini memiliki kesamaan dengan penelitian yang akan diteliti oleh peneliti yakni mengenai peran ibu bekerja (ibu pedagang di pasar) namun terdapat perbedaan. Penelitian 
ini berfokus pada peran ibu-ibu bekerja paruh waktu di pasar dalam menumbuhkan kemandirian. Hal ini belum pernah dilakukan penelitian sebelumnya di Pasar Sekaran Kecamatan Sekaran Kabupaten Lamongan.

Ibu bekerja paruh waktu adalah kerja sampingan ibu rumah tangga dengan jam waktu mampu disesuaikan oleh pekerja ( Azizah, 2017). Ibu bekerja paruh waktu atau yang biasanya dikenal dengan pekerjaan "part time" bekerja dengan waktu jam kerjanya yang pendek, yang fleksibel atau setengah dari waktu jam kerja pada umumnya. Ibu memiliki dua peran penting bagi perkembangan anak yakni (1) Ibu berperan sebagai pendidik bagi anak (Ceka, 2016) mengatakan bahwa Ibu adalah pepatah guru yang pertama dan terbaik dalam keluarga menciptakan perlindungan anak dalam sugesti. Orang tua bertanggung jawab atas perkembangan anak untuk membuat anak-anak tumbuh menjadi penuh kepribadian. Tugas ibu adalah sebagai pendidik untuk anak-anaknya. Ibu mendidik perilaku kemandirian termasuk dalam perilaku sosial juga perkembangan intelektual. Anak mampu menyampaikan emosionalnya dengan baik dengan cinta dan perhatian ibu dan penuh kasih sayang. Peran ibu dalam pendidikan anak juga memberikan dasar pendidikan, sikap dan ketrampilan dasar. Seperti halnya budi pekerti sopan santun, estetika, kasih sayang, rasa aman, dasar-dasar mematuhi peraturan dan melakukan kebiasaan baik seperti beribadah, berdoa dan berbuat baik (Zahrok, 2018). (2) Ibu berperan sebagai pemenuhan kebutuhan dasar bagi anak. Ada tiga kebutuhan dasar yang harus didapatkan oleh anak menurut Hurlock dalam jurnal (Fitriyani et al., 2016). kebutuhan-kebutuhan dasar anak-anak diantaranya: 1) kebutuhan fisik, 2) kebutuhan emosional, 3) kebutuhan stimulasi. Adapun penjelasannya adalah sebagai berikut: a) kebutuhan fisik dapat dipenuhi apabila anak mengkonsumsi makanan sesuai dengan kebutuhan umurnya,pemantauan tumbuh kembang, pemeriksaan kesehatan, pengobatan rehabilitasi, imunisasi, pakaian, pemukiman yang sehat, dan lain-lain. b) Kebutuhan emosional meliputi segala hubungan yang erat, hangat dan menimbulkan rasa aman serta percaya diri sebagai dasar bagi perkembangan selanjutnya. c) Kebutuhan stimulasi atau pendidikan meliputi segala aktivitas yang dilakukan mempengaruhi proses berpikir, berbahasa, sosialisasi dan kemandirian seorang anak.

Kemandirian biasanya disebut dengan otonomi ataupun independen berasal dari kata bahasa Inggris "independence or autonomy" yang memiliki makna kemandirian. Mandiri merupakan kemampuan anak untuk melakukan suatu hal tanpa bergantung kepada orang lain, melakukan segala aktivitasnya dengan sendiri. Anak-anak yang mandiri adalah anakanak yang aktif, independen, kreatif, kompeten dan spontan. Mastari (2011) menyebutkan bahwa mandiri merujuk pada percaya diri dalam sumber-sumber yang ada pada dirinya untuk berhadapan dengan situasi yang dihadapinya. Anak mampu mengatur diri sendiri tanpa meminta bantuan kepada orang lain.mampu menguasai dan menginternalisasikan secara mandiri (Sa'diyah, 2017).

Dalam teori kemandirian yang dikembangkan steinberg (1995) dalam (Budiman, 2016) memaknai istilah independence dan autonomy memiliki makna sama yakni kemandirian. Steinberg mengungkapkan bahwa "independence generally refers to individuals capacity to behave on their own". Anak yang sudah mencapai independence mampu menjalankan atau melakukan sendiri aktivitas hidup terlepas dari pengaruh kontrol orang lain termasuk orang tua. Kemandirian menurut Steinberg (2014) terdiri dari tiga aspek, yaitu kemandirian emosional, kemandirian perilaku dan kemandirian nilai. Kemandirian emosional merupakan aspek kemandirian kemandirian yang berhubungan dengan perubahan kedekatan individu dengan orang lain, terutama orang tua. Kemandirian perilaku merupakan kemampuan untuk mengambil keputusan secara mandiri dan bertanggungjawab atas pilihan yang diambil. Kemandirian nilai merupakan pengembangan suatu keyakinan yang akan membimbing pemikiran dan perilaku seseorang antara benar dan salah (Husna, 2018).

Strategi orang tua menumbuhkan kemandirian anak adalah usaha para orang tua untuk menumbuhkan sebuah tujuan yakni anak memiliki kemampuan kemandirian dengan baik. Adapun strategi yang dilakukan orang tua dalam menumbuhkan kemandirian anak 
(Fitria, 2016) adalah sebagai berikut: 1) Orang tua menerapkan pembiasaan pada anak Cara efektif dalam pembentukan kepribadian anak dapat dilakukan melalui pembiasaan. Awalnya pembiasaan dapat dilakukan dari peniruan dan pengulangan yang dilakukan di bawah bimbingan orang tua. Apabila dilakukan secara berkelanjutan maka akan menjadi kebiasaan yang tidak dapat ditinggalkan. Kebiasaan yang dilakukan orang tua saat menumbuhkan kemampuan kemandirian anak misalnya membiasakan anak bangun pagi, membiasakan anak untuk tidak manja, membiaskan anak berangkat sekolah tepat waktu, membiasakan anak untuk pergi dan pulang dengan sendiri,membiasakan anak tidak bergantung pada orang lain, membiasakan anak membereskan kepentinganya sendiri, membiasakan anak disiplin dengan waktu dan lain sebagainya. Yang berhubungan dengan dorongan kepada anak untuk melakukan segala apapun dengan mandiri memiliki dampak besar terhadap perkembangan anak dalam mengolah sosial dan emosionalnya (Safitri, dkk, 2018).

2) Orang tua menerapkan komunikasi dan bimbingan pada anak. Kualitas hubungan antara orang tua dan anak ditentukan oleh baik atau buruknya komunikasi. Anak usia dini memiliki rasa ingin tahu yang kuat. Anak usia dini akan sering-sering bertanya kepada orang tua yang anak anggap orang tua lebih tahu darinya. Apabila anak merasa didengarkan oleh orang tua akan merasa nyaman. Hal tersebut membuat anak untuk menceritakan segala hal dan orang tua mampu menyampaikan pesan kepada anak dan diterima dengan baik Apabila komunikasi terjalin dengan baik akan membantu orang tua dalam menanamkan kemandirian.(Safitri et al., 2018) Pada saat anak mengalami permasalahan atau kesulitan orang tua selalu sigap dalam memberikan solusi atau bentuk bimbingan kepada anak tentang apa yang seharusnya dilakukan oleh anak. 3) Orang tua berkolaborasi dalam menerapkan pola asuh dan aturan-aturan keluarga pada anak.Ayah dan ibu hendaknya bekerjasama dalam pengasuhan anak. menyamakan presepsi tentang aturan-aturan yang disepakati bersama pasangan tentang menumbuhkan kemandirian. Misalnya di dalam rumah tangga sudah disepakati pada usia 5-6 tahun anak sudah mampu mengambil dan membereskan makanannya. Ibu menerapkan aturan tersebut, namun ayah tidak menerapkan aturan tersebut dikarenakan kasihan. Akibatnya akan menjadikan perbedaan presepsi dalam memberikan pembiasaan pada anak. sehingga anak akan bersikap lebih manja kepada ayah yang memberi kasihan kepadanya.

\section{METODOLOGI}

Penelitian ini Penelitian ini dilaksanakan pada tempat bermukimnya pedagang Pasar Sekaran yang berada di Desa Sekaran Kecamatan Sekaran Kabupaten Lamongan serta di desa pangean kecamatan maduran kabupaten lamongan. Metode ini dipilih untuk menjabarkan menguraikan dan menemukan sebab akibat pada anak yang memiliki kemandirian di pasar. Peneliti mengamati 2 anak dan 2 orang tua FIZ ibunya bernama TIN dan KIL ibunya bernama NI. Peneliti mengamati segala aktivitas anak dirumah pada saat ibu bekerja paruh waktu, pada saat anak dirumah dengan orang tua dan keluarga, serta aktivitas anak pada saat para ibunya pergi ke surabaya dari jam 11.00 sampai jam 19.00 anak-anak berada dirumah tanpa di dampingi orang dewasa dan tanpa ikut ibunya.

Dalam hal ini peneliti mengamati kemandirian anak di lingkungan rumah dan lingkungan sebaya, peran ibu yang bekerja paruh waktu dipasar dalam mendidik anak, strategi yang digunakan oleh ibu untuk menumbuhkan kemandirian anak. Data dan sumber data diperoleh menggunakan teknik observasi lapangan mengamati aktivitas anak dan ibu, wawancara ibu, lingkungan sekitar serta dokumentasi. Metode penelitian ini menggunakan metode kualitatif studi kasus dengan teknik analisis data Miles dan Hubermen untuk mengidentifikasi permasalahan di lapangan tentang kemampuan kemandirian anak serta bagaimana cara orang tua menumbuhkan kemandirian tersebut di identifikasi dengan terperinci. Tahapan penelitian ini mengacu kepada tiga komponen model Miles dan Huberman. Adapun komponen analisis data Miles dan Hubermen, yaitu 1) data condesation, 2) 
data display dan 3) conclusion drawing/verification (Craswell, 2014). Instrumen di validasi oleh satu dosen ahli kualitatif.

Observasi dilakukan secara langsung. Peneliti ikut terlibat langsung dalam kegiatan yang dilakukan anak, bentuk-bentuk kemandirian anak dengan menggunakan pedoman observasi dengan mendokumentasi setiap kegiatan anak. peneliti juga mengamati aktivitas ibu yang berinteraksi dengan anak sehari-hari,. Peneliti melakukan wawancara kepada ibu tentang bentuk-bentuk kemandirian anak, strategi ibu dalam menumbuhkan kemandirian anak di usia 5-6 tahun.

\section{HASIL DAN PEMBAHASAN}

\section{Peran ibu bekerja paruh waktu di pasar sekaran dalam menumbuhkan kemandirian anak usia 5-6 tahun}

Pada umumnya yang berperan dalam mencari nafkah adalah ayah. Namun di kasus ini ibu memiliki kesibukan mencari nafkah juga dengan berjualan baju di pasar Sekaran Lamongan sesuai pernyataan (Herdiyanti, 2018) Awalnya kesetaraan gender adalah sebuah polemik yang terjadi di masyarakat. Polemik tersebut tentang peran perempuan di rumah tangga. Namun seiring berjalanya waktu anggapan tersebut mampu dibiaskan oleh para wanita. Bahwa aktivitas perempuan yang telah berhasil memberikan peluang bahwa perempuan juga terlibat dalam aktivitas publik untuk memenuhi kebutuhan dan meningkatkan kesejahteraan hidup keluarga bersama. Berdasarkan kenyataan yang terjadi itu mayoritas wanita yang bekerja di luar rumah tidak mengalami hambatan atau masalah dengan keluarga karena dukungan dari suami atau keluarga sudah menjadi yang utama modal bagi perempuan untuk bekerja dan bekerja di luar rumah. Selain bekerja ibu tidak bisa mengabaikan perannya di dalam keluarga antara lain: 1) Peran ibu memberikan pendidikan bagi anak. seperti halnya memberikan dasar pendidikan, sikap dan ketrampilan dasar. Seperti halnya budi pekerti sopan santun, estetika, kasih sayang, rasa aman, dasar-dasar mematuhi peraturan dan melakukan kebiasaan baik seperti beribadah, berdoa dan berbuat baik. Hal ini sesuai dengan hasil wawancara peneliti yang dilakukan oleh Bu TIN sebagai orang tua FIZ dan Bu NIS sebagai orang tua KIL. Memiliki kesamaan yakni memberikan dasar pendidikan, sikap dan ketrampilan dasar. Seperti halnya budi pekerti sopan santun sangat ditekankan oleh ibunya contohnya pada saat bertemu tetangga ibunya memberikan contoh untuk menyapa tetangganya. estetika seperti halnya ibu FIZ mengajak bersama untuk membereskan mainan, kasih sayang, rasa aman, dasar-dasar mematuhi peraturan selalu ditekankan kepada anak-anaknya untuk mendengarkan orang dewasa ketika memberikan wejangan (aturan). dan melakukan kebiasaan baik seperti beribadah contohnya pada saat jam sholat selalu di ajak oleh orang tuanya untuk melakukan sholat, berdoa sebelum tidur, sebelum belajar, sebelum dan sesudah makan, muroja'ah hafalan surat pendek, dan berbuat baik kepada sesama serta berbagi

Temuan di atas sejalan dengan pendapat Tugas ibu sebagai pendidik menurut Zahrok (2018) bahwa tugas ibu adalah sebagai pendidik untuk anak-anaknya. Ibu mendidik perilaku kemandirian termasuk dalam perilaku sosial juga perkembangan intelektual. Anak mampu menyampaikan emosionalnya dengan baik dengan cinta dan perhatian ibu dan penuh kasih sayang. 2) Ibu berperan sebagai pemenuhan kebutuhan dasar bagi anak. Peran ibu dalam perkembangan anak sangat penting. Ada tiga kebutuhan dasar yang harus didapatkan oleh anak menurut Hurlock dalam jurnal (Fitriyani et al., 2016) antara lain: a) kebutuhan fisik Hasil temuan di lapangan terdapat kesaamaan yang dilakukan oleh bu TIN dan bu NIS dalam perannya sebagai ibu. Misalnya menyiapkan makanan terutama pada saat meninggalkan anaknya di rumah sendirian ibu dan ayah pergi ke surabaya untuk grosir pakaian. Dalam memenuhi kebutuhan kesehatan sebagai orang tua Bu NIS dan BU TIN selalu tanggap apabila anaknya sakit harus cepat-cepat periksa ke dokter. b) Kebutuhan emosional . Dalam hasil wawancara terdapat kesamaan . ibu memberikan kebebasan untuk menyampaikan Pendapat dan ide sesuai apa yang di inginkan oleh anak-anaknya. Ibu selalu berusaha menuruti 
permintaan anak. Namun ibu juga memberikan kepercayaan dan meminta anaknya untuk bertanggugjawab sesuai dengan apa yang dikehendaki. Perbedaannya apabila FIZ melakukan kesalahn berulang-ulang bu TIN akan bersuara nada tinggi dan mencubit FIZ. Berbeda dengan KIL apabila KIL melakukan kesalahan berkali-kali Bu NIS hanya mengeluarkan nada tinggi tanpa mencubit. C) Kebutuhan stimulasi atau pendidikan meliputi segala aktivitas yang dilakukan mempengaruhi proses berpikir, berbahasa, sosialisasi dan kemandirian seorang anak. Hasil temuan terdapat kesamaan peran ibu TIN dan bu NIS yakni Setiap sore anak-anak wajib mengaji. Dan di malam hari FIZ harus belajar mereview kegiatan-kegiatan yang diberikan oleh guru di sekolah melalui daring. Hal ini berbeda dengan KIL belajar ditemani ibu NIS setelah pulang dari pasar. Ibu NIS juga melakukan pendekatan kepada ustadz nya tentang perkembangan belajar KIL. Gambaran peran ibu bekerja paruh waktu disajikan pada tabel 1 .

\section{Tabel 1. Peran Ibu bekerja paruh waktu}

\begin{tabular}{|c|c|}
\hline & Hasil dan Deskripsi \\
\hline $\begin{array}{l}\text { Peran Ibu Bekerja } \\
\text { paruh waktu }\end{array}$ & $\begin{array}{l}\text { 1. Peran ibu mengatur segala hal yang ada di keluarga } \\
\text { 2. Ibu berperan untuk memenuhi gizi misalnya menyiapkan makanan } 4 \\
\text { sehat } 5 \text { sempurna } \\
\text { 3. ibu berperan untuk pendidikan misalnya mengenalkan lingkungan } \\
\text { sekitar, menjawab pertanyaan anak dengan edukasi yang tepat, } \\
\text { mengulang kembali materi yang diberikan oleh guru atupun ustadz } \\
\text { dan tingkah laku. } \\
\text { 4. ibu beperan memberikan contoh perilaku kebaikan anak, bertutur kata } \\
\text { yang sopan, selalu mendengarkan cerita bersama teman-teman dan } \\
\text { lingkungan Sekitarnya } \\
\text { 5. memberikan reward dalam bentuk jajan, mainan, buku dll. }\end{array}$ \\
\hline
\end{tabular}

\section{Dimensi Kemandirian Anak}

Kemandirian Emosional (Emotional Autonomy) Steinberg (2014) menjelaskan bahwa Kemandirian Emosional adalah aspek kemandirian yang berhubungan dengan perubahan kedekatan individu dengan orang lain terutama orang tua (Husna, 2018). Individu pada fase ini tidak lagi bergantung pada orang tua ketika membutuhkan bantuan. Anak mencoba melakukan segala hal dengan caranya sendiri sebelum meminta bantuan kepada orang tuanya. Anak juga memiliki hubungan sosial emosional dengan orang lain selain orang tua misalnya dengan kakak, saudara, tante, om, tetangga, kerabat dekat, dan teman sebaya .Dalam kemandirian emosional FIZ dan KIL sangat tidak bergantung pada orang tua, anak yang tidak cengeng, tidak egois, tertib, tidak meroyok milik orang lain,sabar, mampu menagtur emosi dengan baik. Namun perbedaannya KIL tergolong anak yang susah mengontrol emosinya apabila dengan adiknya seringkali iri dan berebut dengan adik. Pada FIZ tergolong anak yang seringkali mengabaikan nasihat ibunya. Kemandirian behavioral (Behavioral Autonomy) Kemandirian behavioral disebut dengan kemandirian perilaku merupakan kemampuan untuk mengambil keputusan secara mandiri dan bertanggung jawab atas pilihan yang diambil (Steinberg, 2014). Anak mampu menerima konsekuensi dari keputusan yang diambil namun bukan berarti anak tidak memerlukan masukan dari orang lain. Hal ini melatih kemandirian sejak anak usia dini. Pada proses perkembangan kemandiran pada anak yang pertama kali berkembang adalah kemandirian emosional. Apabila anak mampu mandiri secara emosional maka selanjutnya perkembangan kemandirian perilaku juga akan mengikuti. Kemandirian tingkah laku ditandai oleh anak menyadari adanya resiko dari tingkah laku. Bertanggung jawab atas konsekuensi dari keputusan yang diambilnya, memiliki rasa percaya diri dengan mengatasi sendiri masalahnya, berani mengemukakan ide serta anak mampu menyesuaikan kondisi yang ada. Kemandirian Nilai (Values Autonomy). Hasil lapangan diperoleh bahwa FIZ dan KIL memiliki kemampuan percaya diri yang tinggi, memiliki kemampuan 
beradaptasi dengan cepat, suka berkumpul dengan teman-temannya, juga suka dengan tantangan dan hal-hal baru dan sangat bertanggung jawab dengan keputusannya. Diperkuat oleh temuan di lapangan Kemandirian nilai merupakan pengembangan suatu keyakinan yang akan membimbing pemikiran dan perilaku seseorang tentang benar dan salah ataupun baik buruk (Husna, 2018). Anak memiliki keyakinan atas keputusan yang di ambilnya. Anak juga mampu mengetahui akan nilai yang terkandung baik, buruk ataupun benar dan salah. Kemandirian nilai berkembang paling akhir setelah kemandirian emosional dan kemandirian nilai. Dimenasi kemandirian anak disajikan pada tabel 2.

Tabel 2. Dimensi Kemandirian Anak

\begin{tabular}{|c|c|}
\hline & Hasil dan Deskripsi \\
\hline \multirow[t]{3}{*}{$\begin{array}{l}\text { Dimensi } \\
\text { Kemandirian }\end{array}$} & $\begin{array}{l}\text { 1. Bentuk Kemandirian Emosional (Emotional Autonomy) antara lain: } \\
\text { tidak cengeng, tidak egois, tertib, tidak meroyok milik orang } \\
\text { lain,sabar, mampu mengatur emosi dengan baik, namun terkadang } \\
\text { masih sering menghiraukan ibunya }\end{array}$ \\
\hline & $\begin{array}{l}\text { 2. Bentuk Kemandirian Perilaku antara lain: kemampuan untuk } \\
\text { mengambil keputusan secara mandiri dan bertanggung jawab atas } \\
\text { pilihan yang diambil. Bertanggungjawab pada saat digigit ulat } \\
\text { mencoba mengobati }\end{array}$ \\
\hline & $\begin{array}{l}\text { 3. Kemandirian Nilai (Values Autonomy) pengembangan suatu } \\
\text { keyakinan yang akan membimbing pemikiran dan perilaku } \\
\text { seseorang tentang benar dan salah ataupun baik buruk. }\end{array}$ \\
\hline
\end{tabular}

\section{Strategi Orang tua Menumbuhkan Kemandirian Anak Usia 5-6 tahun}

Strategi orang tua menumbuhkan kemandirian anak adalah usaha para orang tua untuk menumbuhkan sebuah tujuan yakni anak memiliki kemampuan kemandirian dengan baik. Adapun strategi yang dilakukan orang tua dalam menumbuhkan kemandirian anak (Fitria, 2016). Orang tua menerapkan pembiasaan pada anak pembiasaan dapat dilakukan dari peniruan dan pengulangan yang dilakukan di bawah bimbingan orang tua. Apabila dilakukan secara berkelanjutan maka akan menjadi kebiasaan yang tidak dapat ditinggalkan. Orang tua menerapkan komunikasi dan bimbingan pada anak

Hasil observasi dan wawancara di lapangan menunjukkan bahwa strategi yang dilakukan orang tua dalam menumbuhkan kemandirian anak antara lain: Orang tua berkolaborasi dalam menerapkan pola asuh dan aturan-aturan keluarga pada anak. Dalam hasil wawancara kepada bu TIN dan bu NIS menyatakan bahwa ayah dan ibu bekerjasama dalam mendidik dan merawat anak dengan menyamakan presepsi tentang aturan-aturan yang disepakati bersama pasangan tentang menumbuhkan kemandirian. Orang tua menerapkan komunikasi dan bimbingan pada anak membiasakan saling menghargai. Ibu atau anak diberi ruang untuk bicara menyampaikan pendapat, keluh kesah, bercerita apapun, serta keterbukaan kepada anak. Selengkapnya disajikan pada tabel 3.

Tabel 3. Strategi ibu dalam menumbuhkan kemandirian anak usia 5-6 tahun

\begin{tabular}{lll}
\hline \multicolumn{4}{c}{ Hasil dan Deskripsi } \\
\hline $\begin{array}{l}\text { Strategi } \\
\text { ibu }\end{array}$ & 1. Orang tua berkolaborasi dalam menerapkan pola asuh dan aturan- \\
bekerja & 2. $\begin{array}{l}\text { ayah duan keluarga pada anak. } \\
\text { memberikan pendidikan pada anak. }\end{array}$ \\
& 3. orang tua menerapkan komunikasi dan bimbingan pada anak \\
\hline
\end{tabular}




\section{SIMPULAN}

Ibu berperan sebagai pendidik bagi anak dan ibu berperan sebagai pemenuhan kebutuhan dasar bagi anak. strategi yang mampu diterapkan oleh ibu bekerja paruh waktu. Strategi menumbuhkan kemnadirian anak adalah sebagai berikut: Orang tua menerapkan pembiasaan pada anak pembiasaan dapat dilakukan dari peniruan dan pengulangan yang dilakukan di bawah bimbingan orang tua. Orang tua menerapkan komunikasi dan bimbingan pada anak. Kualitas hubungan antara orang tua dan anak ditentukan oleh baik atau buruknya komunikasi. Orang tua berkolaborasi dalam menerapkan pola asuh dan aturan-aturan keluarga pada anak. Ayah dan ibu bekerjasama dalam pengasuhan anak.

\section{UCAPAN TERIMAKASIH}

Kami sampaikan terima kasih Ibu Dr. Nurbiana Dhieni, M. Psi., dan Ibu Dr. Sri Wulan, S.Pd, M.Si - Fakultas Ilmu Pendidikan Universitas Negeri Jakarta, selaku dosen pembimbing dan kepada semua pihak yang telah membantu dalam menyelesaikan artikel jurnal ini, semoga mendapatkan balasan dari Allah SWT. Aamin.

\section{DAFTAR PUSTAKA}

Ahmad Zakaria. (2019). Peran Ganda Perempuan Dalam Memenuhi Kebutuhan Ekonomi Keluarga. universitas negeri jakarta.

Atik Yuliani. (2007). Penanaman Nilai Kemandirian Pada Anak Usia Dini (Studi Pada Keluarga di RW 05 Kelurahan Sindangkasih Kecamatan Beber Cirebon). Journal of Food System Research, 14(2), 70-75. https:// doi.org/10.5874/ifsr.14.2_70

Barnett, M. A., Shanahan, L., Deng, M., Haskett, M. E., \& Cox, M. J. (2010). Independent and Interactive Contributions of Parenting Behaviors and Beliefs in the Prediction of Early

Childhood Behavior Problems. 43-59. https:// doi.org/10.1080/15295190903014604

BPS. (2018). Badan Pusat Statistik Sekaran Lamongan.

Budiman, N. (2016). Perkembangan Kemandirian Pada Remaja. 1-12.

Buehler, C., \& Brien, M. O. (2011). Mothers ' Part-Time Employment: Associations With Mother and Family Well-Being. 25(6), 895-906. https:// doi.org/10.1037/a0025993

Ceka, A. (2016). The Role of Parents in the Education of Children. 7(5), 61-64.

Cordovil, R., Lopes, F., \& Neto, C. (2015). Children's (in)dependent mobility in Portugal. Journal of Science and Medicine in Sport, 18(3), 299-303. https:// doi.org/10.1016/j.jsams.2014.04.013

Craswell, J. W. (2014). Research Design Qualitative, Quantitative and Mixed Methods Approaches Fourth Edition. London: Sage Publications Ltd.

Dahlquist, L. M., Power, T. G., Hahn, A. L., Hoehn, J. L., Thompson, C. C., Herbert, L. J., ... Bollinger, M. E. (2015). Parenting and independent problem-solving in preschool children with food allergy. Journal of Pediatric Psychology, 40(1), 96-108. https://doi.org/10.1093/jpepsy/jsu087

Dhingra, V., \& Keswani, S. (2019). Impact of Working and Non - Working Mothers on Development of their Children in Madhya Pradesh. International Journal of Research in Advent Technology, 7(3), 1369-1375. https:// doi.org/10.32622/ijrat.732019104

Dina Mei Puspitasari. (2015). Strategi Peningkatan Kemandirian Anak Usia Dini Di Tk. Dharma Wanita Brumbung 1 Kediri. Jurnal Psikologi Dan Psikologi Islam, 53(9), 16891699. https:// doi.org/10.1017/CBO9781107415324.004

Dinas Kependudukan dan Pencatatan Sipil kabupaten lamongan. (2018). No Title. Retrieved from bps.go.id website: https:/ / lamongankab.bps.go.id/statictable/2018/02/08/958/jumlah-pendudukmenurut-kecamatan-dan-kelompok-umur-di-kabupaten-lamongan-2016.html

Dorothy Einon. (2006). Learning Early (Grasindo, Ed.). Jakarta.

Erikson, E. (1987). childhood and society. 
Etikawati, A. I. (2017). Apersepsi Mengenai Figur Ayah Dan Ibu Pada Anak-Anak Di Yogyakarta. Jurnal Penelitian, 17(2). Retrieved from http://ejournal.usd.ac.id/index.php/JP/article/view/790

Fitria, D. (2016). Peran Ibu Yang Bekerja Terhadap Pendidikan Anak. Ilmu Sosiologi.

Fitriyani, F., Nurwati, N., \& Humaedi, S. (2016). Peran Ibu Yang Bekerja Dalam Pemenuhan Kebutuhan Dasar Anak. Prosiding Penelitian Dan Pengabdian Kepada Masyarakat, 3(1). https://doi.org/10.24198/jppm.v3i1.13626

Hancock. (2014). An introduction to Qualitative research. University of Nottingham. Nottingham: Trent focus group.

Hastasari, C., Anggitya, P. T., \& Musslifah, A. R. (2015). Pola Asuh Balita Ibu-Ibu Kelompok Sasaran Pada Program Kegiatan Bina Keluarga Balita Usia 0-12 Bulan Dusun Gandekan Kartasura. Informasi, 1. https://doi.org/10.21831/informasi.v45i1.7765

Herdiyanti, H. (2018). Role of Career Women in Families: (Study of the Existence of Career Women in Families in Balunijuk Village). Society, 6(1), 1-7. https://doi.org/10.33019/society.v6i1.59

Hukum, B., Organisasi, D. A. N., Pendidikan, K., \& Kebudayaan, D. A. N. (2017). Permendikbud Tentang.

Hurlock, B. E. (1987). Perkembangan Anak; Jilid 2. jakarta: Erlangga.

Husna, A. N. (2018). Kemandirian Emosional Pada Remaja Awal: Studi Di Smpn 1 Margaasih Kabupaten Bandung. Journal of Psychological Science and Profession, 2(3), 222. https://doi.org/10.24198/jpsp.v2i3.21599

john Creswell. (2015). Riset Pendidikan (Perencanaan, Pelaksanaan, dan Evaluasi Riset Kualitatif \& Kuantitatif (lima). yogyakarta: Pustaka Belajar.

Lara, L., \& Saracostti, M. (2019). Effect of parental involvement on children's academic achievement in Chile. Frontiers in Psychology, 10(JUN), 1-5. https://doi.org/10.3389/fpsyg.2019.01464

Malone, K., \& Rudner, J. (2011). Global Perspectives on Children's Independent Mobility: A Socio-Cultural Comparison and Theoretical Discussion of Children's Lives in Four Countries in Asia and Africa. Global Studies of Childhood, 1(3), 243-259. https://doi.org/10.2304/gsch.2011.1.3.243

Martono, T. (2017). suarabanyuurip.com.

Maslow, A. (1968). TOWARD A PSYCHOLOGY Second Edition.

McDowell, K., Jack, A., \& Compton, M. (2018). Parent Involvement in Pre-Kindergarten and the Effects on Student Achievement. The Advocate, 23(6). https://doi.org/10.4148/2637-4552.1004

Moleong, L. J. (2010a). Metode Penelitian Kualitatif. Bandung: Remaja Rosdakarya.

Moleong, L. J. (2010b). Metodologi Penelitian Kualitatif. Bandung: PT. Remaja Rosdakarya.

Myrnawaty Crie Handini. (2012). Metodologi Penelitian Untuk Pemula. Jakarta: FIP Press.

Nauli, V. A., Karnadi, K., \& Meilani, S. M. (2019). Peran Ibu Pedagang Pasar 24 Jam Terhadap Perkembangan Moral Anak (Penelitian Studi Kasus di Kota Bekasi). Jurnal Obsesi : Jurnal Pendidikan Anak Usia Dini, 3(1), 241. https:/ / doi.org/10.31004/obsesi.v3i1.179

Novan Ardy Wiyani, 1985-; Rose Kusumaning Ratri. (2013). Bina karakter anak usia dini : panduan orang tua \& guru dalam membentuk kemandirian \& kedisiplinan anak usia dini (Rose Kusumaning Ratri, Ed.). Jogjakarta: Ar-Ruzz Media.

Novita, D. (2015). Pengaruh Pola Pengasuhan Orang tua Dan Proses Pembelajaran Di Sekolah Terhadap Tingkat Kreativitas Anak Prasekolah (4-5 Tahun). Jurnal Pendidikan, 16(2), 100-109. https://doi.org/10.33830/jp.v16i2.338.2015

Nur Lailatul Azizah. (2017). Pengaruh Kerja Part Time Terhadap Prestasi Akademik Dan Non Akademik Prodi Pendidikan Agama Islam Tahun 2014 di UIN Sunan Ampel. 1-131.

Pacilli, M. G., Giovannelli, I., \& Spaccatini, F. (2015). Movement, Mobilities and Journeys. Movement, Mobilities and Journeys, 1-21. https:// doi.org/10.1007/978-981-4585-93-4 
Sa'diyah, R. (2017). Pentingnya Melatih Kemandirian Anak. Kordinat, 15(1), 31-46. https://doi.org/10.15408/kordinat.v16i1.6453

Safitri, N., Setiawati, S., \& Aini, W. (2018). Gambaran Penanaman Kemandirian pada Anak Usia Dini oleh Orang Tua dalam Keluarga. Spektrum: Jurnal Pendidikan Luar Sekolah (PLS), 1(1), 84. https:// doi.org/10.24036/spektrumpls.v1i1.9005

Santrock, J. W. (2010). Eucational Phsycology Five Edition.

Sari, E. (2018). the Role of Assistance and Budget Impacts in the Field of Marine and Fisheries on Welfare Conditions of Fishermen Community in Ende District. Jurnal Ekonomi Mercu Buana, 6(1), 78-102. https://doi.org/10.26486/jpsb.v6i1

Sari, M. D. ., \& Deliana, S. M. (2017). Perbedaan kemandirian remaja yang tinggal di pondok pesantren dengan yang tinggal dirumah bersama orang tua. Jurnal Psikologi Ilmiah, 9(1), 74-79.

Saul McLeod. (2018). Erik Erikson's stages of psychosocial development. Retrieved from https:// www.simplypsychology.org/Erik-Erikson.html

Suardani, L., Drs. Ketut Pudjawan, M. P. ., \& Luh Ayu Tirtayani, S. P. M. P. . (2016). Perbedaan Tingkat Kemandirian Anak Usia 5-6 Tahun Dilihat Dari Status Pekerjaan Ibu Di Kelurahan Banyuning Kecamatan Buleleng. E-Journal Pendidikan Anak Usia Dini Universitas Pendidikan Ganesha Jurusan Pendidikan Guru Pendidikan Anak Usia Dini, 4(2), 1-12. Retrieved from https:// ejournal.undiksha.ac.id/index.php/JJPAUD/article/view/7765

Sugiyono. (2007a). Memahami Penelitian Kualitatif. jakarta: Alfabeta.

Sugiyono. (2007b). Memahami Penelitian Kualitatif. Bandung: Alfabeta.

Sugiyono. (2009). Metode Penelitian Pendidikan (pendekatan kuantitatif, kualitatif dan R\&D (cetakan ke). Bandung: Alfabeta.

Suid, Alfiati Syafrina, T. (2017). Analisis Kemandirian Siswa Dalam Proses Pembelajaran Di Kelas Iii Sd Negeri 1 Banda Aceh. Jurnal Pesona Dasar, 1(1), 70-81.

Sunarty, K., Dirawan, G. D., Faculty, E., \& Faculty, E. (2015). Development Parenting Model to Increase the Independence of. 8(10), 107-113. https:// doi.org/10.5539/ies.v8n10p107

Syahid, I. M. (2015). Peran Ibu Sebagai Pendidik Anak Dalam Keluarga Menurut Syekh Sofiudin Bin Fadli Zain. Skripsi, 1-117.

Tohirin. (2012). Metode Penelitian Kualitatif dalam Pendidikan dan Bimbingan Konseling. Jakarta: Rajagrafindo Persada.

Tumbage, S. M. ., Tasik C.M, F., \& Tumengkol, S. M. (2017). Peran Ganda Ibu Rumah Tangga Dalam Meningkatkan Kesejahteraan Keluarga Di Desa Allude Kecamatan Kolongan Kabupaten Talaud. Acta Diurna, VI(2), 2.

Ulfatin, N. (2013). Metode Penelitian Kualitatif di Bidang Pendidikan: Teori dan Aplikasinya. malang: Bayumedia.

Weiss, H. B., Mayer, E., Kreider, H., Vaughan, M., Dearing, E., \& Hencke, R. (2003). Making It Work: Low-Income Working Mothers' Involvement in Their Children's Education. 40(4), 879-901. https:// doi.org/10.3102/00028312040004879

Yuliati, U. (2019). The Analyses of Women Role On Part-Time Workers In Junrejo Batu City. 2(2), 23-34. https://doi.org/10.22219/jpa.v2i2.9663

Zahrok, S., \& Suarmini, N. W. (2018). Peran Perempuan dalam Keluarga IPTEK Journal of Proceedings Series, (5), 61. https://doi.org/10.12962/j23546026.y2018i5.4422 